\title{
Fair Value Non-Current Asset, Koneksi Politik dan Audit Fee
}

\author{
Yeni Anggriani, Helmi Yazid, dan Muhamad Taqi
}

Program Studi Magister Akuntansi, Pascasarjana, Universitas Sultan Ageng Tirtayasa, Serang Jl. Raya Jakarta KM. 4 Pakupatan Serang, 42122, Indonesia

\section{Info Artikel}

Keywords:

Audit Fee; Fair Value Non-

Current Asset; and Political

Conection.

Kata Kunci:

Biaya Audit; Fair Value NonCurrent Asset; dan Koneksi Politik

ISSN (print): 2598-7763

ISSN (online): 2598-7771

$\triangle$ Corresponding Author:

Muhamad Taqi:

Tel. /Fax. +62 877-7101-1961

E-mail:

muhamad.taqi@untirta.ac.id

\begin{abstract}
Abtract
This study aims to determine the effect of fair value non-current asset on the determination of audit fee and to know moderating effect of political connection between fair value non current asset and audit fee in financial companies listed in Indonesia Stock Exchange. The method of research analysis used in this research is descriptive method. Population in this research is financial companies listed in Indonesia Stock Exchange with sample of 25 companies by using purposive sampling method in period 2016-2018. The data used is secondary data collected by documentation technique. In analyzing the data, this study used a test tool of ordinary least square (OLS) analysis and moderation regression analysis (MRA). The result of this research indicates that fair value non-current asset influence audit fee and this research show that the political connection can't moderate of fair value non-current asset toward auditfee.
\end{abstract}

Citation: Yeni, A., Yazid, H., and Taqi, M. (2020). Fair Value Non-Current Asset Dan Koneksi Politik Terhadap Audit Fee. AFRE Accounting and Financial Review. 3 (2): 158-163

\begin{abstract}
Abstraks
Penelitian ini bertujuan untuk mengetahui pengaruh fair value non-current asset terhadap fee audit dan untuk mengetahui moderasi koneksi politik dalam pengaruh antara fair value non-current asset dan fee audit pada perusahaan sektor keuangan yang terdaftar di Bursa Efek Indonesia. Metode analisis penelitian yang digunakan dalam penelitian ini adalah metode deskriptif. Populasi dalam penelitian ini adalah perusahaan sektor keuangan yang terdaftar di Bursa Efek Indonesia dengan sampel sebanyak 25 perusahaan dengan menggunakan metode purposive sampling pada periode 2016-2018. Data yang digunakan adalah data sekunder yang dikumpulkan dengan teknik dokumentasi. Dalam menganalisis data, penelitian ini menggunakan alat uji berupa analisis regresi linier berganda serta analisis regresi moderasi (MRA). Hasil dari penelitian ini menunjukkan bahwa fair value non-current asset berpengaruh positif terhadap fee audit dan penelitian ini menunjukkan bahwa koneksi politik tidak dapat memoderasi hubungan antara fair value non-current asset terhadap fee audit.
\end{abstract}

JEL Classification: G34, M42

DOI: https://doi.org/10.26905/afr.v3i2.4708

\section{PENDAHULUAN}

Dalam hubungan keagenan prinsipal memberikan kewenangan kepada agen untuk mengelola perusahaan demi kepentingannya. Namun, Jensen \& Meckling (1976) menga-sumsikan prinsipal dan agen cenderung memaksimumkan kesejahteraannya masing-masing se- hingga ada kemungkinan jika agen tidak selalu bertindak demi kepentingan terbaik prinsipal. Hal ini menyebabkan terjadinya konflik kepentingan antara agen dan prinsipal.

Untuk meminimalkan konflik perbedaan kepentingan dan asimetri informasi, perusahaan membutuhkan pihak lain yang bersifat independen sebagai mediator antara pemegang saham 
Fair Value Non-Current Asset, Koneksi Politik dan Audit Fee

Yeni Anggriani, Helmi Yazid, dan Muhamad Taqi

(prinsipal) dan manajer (agen) (Nicolin dan Sabeni, 2013). Pihak ketiga yang independen yaitu auditor yang bertugas untuk melaksanakan proses audit laporan keuangan yang dianggap dapat mengurangi asimetri informasi dalam perusahaan.

Setelah proses audit atas laporan keuangan dilakukan, perusahaan berkewajiban untuk membalas jasa akuntan publik dengan memberikan fee audit. Masalah fee merupakan suatu permasalahan yang dilematis karena auditor mendapat fee dari perusahaan yang diaudit, dimana disatu sisi auditor harus independen memberikan opininya tapi di sisi lain auditor juga memperoleh imbalan dari perusahaan atas pekerjaan yang dilakukannya (Taqi et al., 2020 dan Herawaty, 2011). Peraturan Pengurus No. 2 Tahun 2016 menyatakan penetapan besaran fee audit yang terlalu rendah dapat menimbulkan keraguan mengenai kemampuan dan kompetensi auditor, selain itu dapat menimbulkan ancaman berupa kepentingan pri-badi yang menyebabkan ketidak patuhan kode etik profesi akuntan publik. Oleh sebab itu kantor akuntan publik dan perusahaan (klien) wajib mengetahui faktorfaktor yang dapat mempe-ngaruhi besaran fee audit.

Kompleksitas jasa audit merupakan salah satu faktor yang dapat mempengaruhi besaran fee audit. Salah satu kompleksitas tugas auditor dalam pengumpulan bukti audit adalah melakukan pengujian fisik atas aset. Apandi et al., (2016) menyatakan dalam perspektif client attribute jumlah aset perusahaan merupakan salah satu faktor yang dinilai paling mempengaruhi besarnya fee audit. Non-current asset merupakan salah satu akun yang seringkali menunjukkan jumlah material dalam laporan keuangan sebagian besar entitas sehingga memiliki kompleksitas tersendiri dalam proses auditnya.

Dalam IFRS 13 Fair Value Measurement diatur ketentuan bahwa aset dinilai menggunakan harga wajar (fair value). Berbeda dengan biaya historis yang menggunakan nilai ketika pembelian, memperoleh fair value untuk aset tetap tidaklah mudah. Dalam penerapannya fair value membutuhkan banyak estimasi, asumsi dan judgment. Auditor harus melakukan evaluasi penggunaan estimasi, asumsi dan judgment yang dilakukan manajemen secara rasional serta menentukan konsistensi pengukuran dalam penggunaan konsep fair value Apandi et al., (2016). Penerapan konsep fair value ini berpengaruh terhadap tang-gung jawab dan kompleksitas tugas serta risiko audit yang diemban auditor sehingga dapat menyebabkan peningkatan fee audit.

Hasil penelitian yang mengkaitkan penggunaan fair value dengan fee audit masih menimbulkan perbedaan. Ettredge et al., (2014); (Yao et al., (2015) menyatakan bahwa penggunaan fair value dapat meningkatkan fee audit. Penelitian lain mengatakan hal yang berbeda, Goncharov et al., (2012) menyatakan bahwa penggunaan fair value dapat menurunkan fee audit. Perbedaan hasil pada penelitian sebelumnya memungkinkan terdapatnya aspek lain yang mempengaruhi pengaruh antara fair value non-current asset dengan fee audit.

Penelitian ini berbeda dengan penelitian sebelumnya yang dilakukan Utamaningsi (2019); Habib et al., (2018); Ariningrum \& Diyanty, (2017); dan Yao et al. (2015) dimana dalam penelitian ini terdapat variabel koneksi politik sebagai variabel moderating antara fair value noncurrent asset dengan fee audit berda-sarkan penelitian Setyawati dan Apandi (2019). Manfaat yang didapat dari perusahaan yang memiliki koneksi politik diantaranya adalah lebih mudah mendapat proyek dari pemerintah, membayar beban pajak lebih sedikit, dan pemerintah lebih mudah melakukan bailout saat perusahaan mengalami kesulitan keuangan. Dalam penelitiannya Wang et al., (2017); Chaney \& Parsley, (2010); Chaney et al. (2007) perusahaan yang memiliki koneksi politik cenderung memiliki kualitas pelaporan keuangan yang lebih rendah dibanding dengan perusahaan yang tidak memiliki koneksi politik.

Penelitian ini diharapkan mampu menjadi pembanding maupun memperbaiki penelitianpenelitian yang telah dilakukan sebelumnya serta sebagai tambahan referensi bagi peneliti selanjutnya. Penelitian ini juga bermanfaat untuk menambah literatur serta memberikan kontribusi penelitian dalam pengembangan teori akuntansi terutama dalam bidang fair value non-current asset, koneksi politik, maupun fee audit. Penelitian ini juga bermanfaat untuk memberikan informasi pengaruh fair value non-current asset terhadap fee audit dengan koneksi politik sebagai variabel pemoderasi di perusahaan, serta memberi implikasi bagi pihak-pihak seperti auditor dalam menentukan fee audit yang rasional, bagi manajemen perusahaan dalam penentuan kebijakan-kebijakan serta menjadi bahan pertimbangan dalam pengambilan keputusan terkait kebijakan penggunaan fair value dalam perusahaan, dan bagi regulator sebagai bahan pertimbangan pembuatan 
kebijakan yang berkaitan dengan penentuan tarif fee audit.

\section{PENGEMBANGAN HIPOTESIS}

Fair Value Non-Current Asset Terhadap Fee Audit

Penggunaan fair value non-current asset dalam pelaporan keuangan dengan menggunakan international financial reporting standard berpengaruh terhadap peningkatan fee audit. Menurut Watts \& Zimmerman (1990) konflik keagenan yang terjadi antara agent dan principal dapat dikurangi melalui proses audit, dimana fee audit yang tinggi dapat mempengaruhi kualitas audit. Auditor memiliki tanggungjawab untuk memastikan bahwa agen melakukan hal yang terbaik bagi principal (Cobb et al., 1995; Nikkinen \& Sahlström, 2004; Uusitalo et al., 2013; dan O'Sullivan, 2000). Tanggung jawab yang tinggi bagi auditor akan berpengaruh terhadap fee audit yang tinggi. Oleh karenanya tanggung jawab dalam menilai kewajaran atas asumsi, estimasi dan judgment dari pelaporan non-current asset yang dibuat manajemen dengan menggunakan fair value berimplikasi pada alokasi waktu dan sumberdaya yang lebih besar, sehingga fee audit yang ditetapkan menjadi lebih tinggi (Yao et al., 2015). Berdasarkan literatur tersebut, maka hipotesis yang diajukan dalam penelitian ini adalah: $\mathrm{H}_{1}$ : Fair value non-current asset berpengaruh positif terhadap fee audit

Fair Value Non-Current Asset Terhadap Fee Audit Yang Dimoderasi Oleh Koneksi Politik

Koneksi politik merupakan tingkat kedekatan hubungan perusahaan dengan pemerintah (Primasari dan Sudarno, 2013). Manfaat yang didapat dari perusahaan yang memiliki koneksi politik diantaranya adalah lebih mudah mendapat proyek dari pemerintah, membayar beban pajak lebih sedikit, dan pemerintah lebih mudah melakukan bailout saat perusahaan mengalami kesulitan keuangan. Dalam penelitiannya Wang et al., (2017); Chaney \& Parsley, (2010); Chaney et al. (2007) perusahaan yang memiliki koneksi politik cenderung memiliki kualitas pelaporan keuangan yang lebih rendah dibanding dengan perusahaan yang tidak memiliki koneksi politik. Oleh karena itu, risiko audit akan menentukan berapa fee audit yang harus dibayar oleh perusahaan diukur dengan berapa banyak usaha diminta auditor untuk melakukan prosedur audit (Ariningrum dan Diyanty, 2017). Risiko in- heren akan dipandang lebih tinggi untuk perusahaan yang memiliki koneksi politik, sehingga monitoring costs menjadi lebih tinggi seperti fee audit.

Teori agensi juga menjelaskan akan muncul potensi konflik kepentingan antara agen dan prinsipal. Konflik kepentingan antara agen dan prinsipal tersebut muncul karena berkurangnya kepercayaan prinsipal terhadap kinerja agen. Untuk meyakinkan prinsipal, perusahaan yang mempunyai koneksi politik cenderung untuk memakai jasa KAP big four untuk mengaudit laporan keuangan perusahaan. KAP big four dipercaya dapat memberikan audit dengan kualitas yang lebih baik. Hal ini karena auditor di KAP big four memiliki pengalaman yang banyak, klien yang lebih banyak, efektifitas dan efisiensi yang lebih baik dibandingkan KAP non big four (Immanuel \& Yuyetta, 2014). Penggunaan jasa KAP big four untuk melakukan jasa audit atas laporan keuangan akan berpengaruh terhadap besaran fee audit yang tinggi.

Perusahaan yang menggunakan fair value dalam penilaian non-current asset akan berpengaruh positif terhadap fee audit yang lebih tinggi dan hal ini akan diperkuat dengan adanya koneksi politik dalam perusahaan. Berdasarkan literatur tersebut, maka hipotesis selanjutnya yang diajukan dalam penelitian ini adalah:

$\mathrm{H}_{2}$ : Fair value non-current asset berpengaruh positif terhadap fee audit yang dimoderasi oleh koneksi politik

\section{DATA DAN METODE}

Penelitian ini menggunakan kausal verifikatif dengan pendekatan kuantitatif dalam menguji variabel bebas dan variabel terikat yang memiliki faktor memperkuat atau memperlemah hubungan antara keduanya. Faktor tersebut yaitu koneksi politik yang memperkuat atau memperlemah hubungan antara fair value non-current asset terhadap fee audit. Populasi dari penelitian ini yaitu perusahaan sektor keuangan yang terdaftar di Bursa Efek Indonesia tahun 2016-2018. Perusahaan sektor keuangan yang terdaftar di BEI berjumlah 86 perusahaan, dengan rincian 43 perusahaan perbankan, 14 perusahaan sektor asuransi, 12 perusahaan efek dan 17 perusahaan pembiayaan. Berdasarkan pemilihan sampel dengan purposive sampling maka sampel penelitian ini berjumlah 75 perusahaan. Teknik analisis menggunakan MRA. Model regresi yang digunakan dalam penelitian ini adalah sebagai berikut: 
Fair Value Non-Current Asset, Koneksi Politik dan Audit Fee Yeni Anggriani, Helmi Yazid, dan Muhamad Taqi

Analisis Regresi Linier Berganda

$F E E_{\mathrm{it}}=\alpha+\beta_{1} F A I R_{\mathrm{it}}+\beta_{2} S I Z E_{\mathrm{it}}+\beta_{3} \mathrm{KAP}_{\mathrm{it}}+\mathrm{e}$

Analisis Regresi Moderasi (Moderated Regression Analysis)

$$
\begin{gathered}
F E E_{\mathrm{it}}=\mathrm{a}+\beta_{1} \text { FAIR }_{\mathrm{it}}+\beta_{2} P C_{\mathrm{it}}+\beta_{1} \text { FAIR }_{\mathrm{it}}{ }^{*} \beta_{2} P C_{\mathrm{it}}+ \\
\beta_{3} S I Z E \mathrm{it}+\mathrm{B}_{4} \mathrm{KAP}_{\mathrm{it}}+\mathrm{e}
\end{gathered}
$$

Keterangan: FEE: Natural Logaritma Besarnya Fee audit pada Perusahaan i pada tahun ke t; FAIR: Natural Logaritma Besarnya Fair value Non-Current Asset pada Perusahaan i pada tahun ke t; $P C$ : 1 jika perusahaan i mempunyai Koneksi Politik dan 0 jika tidak; SIZE: Natural logaritma Total Asset perusahaan i pada tahun ke t; KAP: 1 jika perusahaan i menggunakan auditor; Big four dan 0 jika tidak; $\alpha$ : konstanta; $\beta$ : koefisien regresi dari variabel bebas dan e: error

\section{HASIL}

Penelitian ini dilakukan pada perusahaan sektor keuangan yang terdaftar di Bursa Efek Indonesia (BEI) periode 2016 sampai dengan 2018. Hasil analisis deskriptif dengan menggunakan SPSS dari variabel-variabel penelitian disajikan pada tabel 1 .

Tabel 1. Statistik Deskripsi

\begin{tabular}{lrrrr}
\hline & Minimum & Maximum & Rerata & Std. Dev. \\
\hline Fee & 19,114 & 22,755 & 20,861 & 1,101 \\
Fair & 23,151 & 29,013 & 26,255 & 1,784 \\
PC & 0 & 1,0 & 0,480 & 0,503 \\
Size & 27,691 & 34,326 & 30,534 & 1,886 \\
KAP & 0 & 1,0 & 0,747 & 0,437 \\
\hline
\end{tabular}

Berdasarkan tabel 2 dapat diartikan bahwa variabel fair value non-current asset mempunyai arah koefisien positif 0,175 dengan tingkat signifikansi sebesar 0,038 lebih kecil dari 0,05. Hal tersebut menunjukkan bahwa variabel fair value noncurrent asset berpengaruh positif signifikan terhadap fee audit. Variabel koneksi politik memiliki arah koefisien negatif $-0,306$ dengan tingkat signifikansi sebesar 0,882 lebih besar dari 0,05. Hal tersebut menunjukkan bahwa variabel koneksi politik tidak berpengaruh positif signifikan terhadap fee audit

\begin{tabular}{|c|c|c|c|}
\hline & Koef. & Std. Error & Prob. \\
\hline (Constant) & 7,890 & 1,517 & 0,000 \\
\hline Fair & 0,175 & 0,083 & 0,038 \\
\hline PC & $-0,306$ & 2,046 & 0,882 \\
\hline Size & 0,249 & 0,078 & 0,002 \\
\hline KAP & 1,003 & 0,152 & 0,000 \\
\hline Moderasi & 0,014 & 0,077 & 0,859 \\
\hline
\end{tabular}

Tabel 2. Hasil Pengujian
Variabel kontrol size memiliki arah koefisien positif 1,003 dengan tingkat signifikansi sebesar 0,002. Hal tersebut menunjukkan bahwa size berpengaruh positif signifikan terhadap fee audit. Variabel kontrol KAP memiliki arah koefisien positif 1,003 dengan tingkat signifikansi sebesar 0,000 . Hal tersebut menunjukkan bahwa variabel KAP berpengaruh positif signifikan terhadap fee audit.

Variabel moderasi yang dihitung dengan mengalikan variabel Fair dan PC memiliki arah koefisien positif 0,014 dengan tingkat signifikansi sebesar 0,859. Dengan demikian koneksi politik tidak dapat memoderasi hubungan antara fair value non-current asset dengan fee audit.

\section{PEMBAHASAN}

\section{Fair Value Non-Current Asset Terhadap Fee Audit}

Fair value non-current asset berpengaruh positif terhadap fee audit. Hasil tersebut mengindikasikan bahwa penggunaan fair value non-current asset dalam pelaporan keuangan perusahaan dengan menggunakan international financial reporting standard (IFRS) dapat meningkatkan jumlah fee audit. Hal ini dikarenakan pelaporan keuangan perusahaan dengan menggunakan fair value dalam menilai non-current asset akan memperluas lingkup pemeriksaan (kompleksitas audit) karena penggunaan fair value dalam menilai non-current asset mengandung estimasi, asumsi dan judgment yang dibuat oleh manajemen yang menyebabkan terjadinya peningkatan effort yang diemban auditor. Hal ini berimplikasi pada alokasi waktu dan sumberdaya yang lebih besar, sehingga fee audit yang ditetapkan menjadi lebih tinggi. Namun di sisi lain, penggunaan fair value non-current asset dalam pelaporan keuangan perusahaan memiliki beberapa keunggulan yaitu dapat menambah nilai aset dalam perusahaan, laporan keuangan menjadi lebih relevan untuk dasar pengambilan keputusan, meningkatkan keterbandingan laporan keuangan, dan informasi lebih dekat dengan apa yang diinginkan oleh pemakai laporan keuangan.

Hasil penelitian ini sejalan dengan agency theory, dimana menurut Watts \& Zimmerman (1990) konflik keagenan yang terjadi antara agent dan principal dapat dikurangi melalui proses audit, dimana fee audit yang tinggi dapat mempengaruhi kualitas audit. Auditor memiliki tanggungjawab untuk memastikan bahwa agen melakukan hal yang terbaik bagi principal (Cobb et al., 1995; Cobb et al., 1995; Nikkinen \& Sahlström, 
2004; Uusitalo et al., 2013; dan O'Sullivan, 2000). Tanggungjawab yang tinggi bagi auditor akan dipengaruhi oleh fee audit yang tinggi. Oleh karenanya tanggungjawab dalam menilai kewajaran atas asumsi, estimasi dan judgment dari pelaporan non-current asset yang dibuat manajemen menggunakan fair value berimplikasi pada alokasi waktu dan sumberdaya yang lebih besar, sehingga fee audit yang ditetapkan menjadi lebih tinggi (Yao et al., 2015).

\section{Fair Value Non-Current Asset Terhadap Fee Audit Yang Dimoderasi Oleh Koneksi Politik}

Koneksi politik tidak dapat memoderasi hubungan antara fair value non-current asset dengan fee audit. Hasil ini mengindikasikan bahwa perusahaan dengan koneksi politik, maupun perusahaan tanpa koneksi politik mendapatkan perlakuan yang sama dari auditor eksternal dalam penetapan fee audit. Oleh karena itu, tidak ada perbedaan penetapan fee audit yang dibebankan oleh auditor eksternal atas jasa profesi yang diberikannya kepada perusahaan tersebut. Selain itu, koneksi politik khususnya di Indonesia lebih dimanfaatkan untuk memperoleh pendapatan yang bersumber dari kemudahan mendapat proyek dari pemerintah dan pajak yang lebh rendah. Hal ini menunjukkan bahwa ada tidaknya koneksi politik tidak mempe-ngaruhi hubungan antara fair value non-current asset terhadap fee audit.

\section{SIMPULAN}

Berdasarkan pada hasil dan pembahasan penelitian dapat ditarik kesimpulan sebagai berikut bahwa Fair value non-current asset berpengaruh positif terhadap fee audit, Koneksi politik tidak dapat memoderasi hubungan antara fair value noncurrent asset terhadap fee audit. Temuan ini mengindikasikan bahwa penggunaan fair value noncurrent asset dalam pelaporan keuangan perusahaan dengan menggunakan international financial reporting standard (IFRS) dapat meningkatkan jumlah fee audit. Hasil ini mengindikasikan bahwa perusahaan dengan koneksi politik maupun perusahaan tanpa koneksi politik mendapatkan perlakuan yang sama dari auditor eksternal dalam penetapan fee audit.

Penelitian ini untuk terbatas jumlah data yang relatif sedikit karena belum banyak perusahaan yang mengungkapkan jumlah fee audit sekaligus menerapkan fair value non-current asset di Indonesia dan untuk koneksi politik hanya melihat kepala negara dan wakil kepala negara, menteri dan wakil menteri, daftar nama anggota DPR, kepala daerah dan wakil kepala daerah yang pernah menjabat, serta adanya hubungan keluarga (suami, istri, anak, cucu, dan saudara kandung) dengan pimpinan partai yang mendapatkan kursi di DPR. Untuk penelitian selanjutnya dapat dilakukan dengan menggali informasi informasi yang lebih mendalam mengenai perusahaan yang mengungkapkan fee audit dan cakupan untuk koneksi politiknya.

\section{DAFTAR PUSTAKA}

Apandi, R. N. N. (2015). Pengaruh Penerapan Fair Value Non Current Asset dan Manajemen Pajak atas Asset Perusahaan terhadap Fee Audit. Jurnal Riset Akuntansi \& Keuangan, 4(3), 1229-1242.

Arens, A.A., Elder, R.J., dan Beasley, M.S. (2008), Auditing dan Jasa Assurance Pendekatan Terintegrasi, Edisi 12, Jilid I, Erlangga, Jakarta.

Arens, A. A., Elder, R. J., dan Beasley, M. S. (2014). Auditing \& Jasa Assurance. (S. Saat, Ed.) (15th ed.). Jakarta: Erlangga.

Apandi, R. N. N., Utama, S., \& Rosieta, H. (2016). The Effect of Corporate Tax Governance, Audit Quality and Tax Exposure on Audit Fee for Companies Enlisted in Indonesia Stock Exchange. Advances in Economics, Business and Management Research, 15, 8-16. https://doi.org/10.2991/gcbme-16.2016.2

Ariningrum, I., \& Diyanty, V. (2017). The Impact of Political Connections and the Effectiveness of Board of Commissioner and Audit Committees on Audit Fees. Business and Finance Journal, 11(4), 53-70. https://doi.org/10.14453/aabfj.v11i4.5

Chaney, P. K., Faccio, M., \& Parsley, D. (2007). The Quality of Accounting Information in Politically Connected Firms. Purdue CIBER Working Papers.

Chaney, P. K., \& Parsley, D. (2010). The Quality of Accounting Information in Politically Connected Firms. MPRA Paper, 21116.

Cobb, I., Helliar, C., \& Innes, J. (1995). Management accounting change in a bank. In Management Accounting Research (Vol. 6, Issue 2, pp. 155-175). https://doi.org/10.1006/mare.1995.1009

Ettredge, M., Fuerherm, E. E., \& Li, C. (2014). Fee pressure and audit quality. Accounting, Organizations and Society, 39(4), 247-263. https://doi.org/10.1016/j.aos.2014.04.002

Goncharov, I., Riedl, E. J., \& Sellhorn, T. (2012). 
Fair Value and Audit Fees. SSRN Electronic Journal. https://doi.org/10.2139/ssrn.1855628

Habib, A., Ranasinghe, D., Muhammadi, A. H., \& Islam, A. (2018). Political connections, financial reporting and auditing: Survey of the empirical literature. Journal of International Accounting, Auditing and Taxation, 31, 37-51. https://doi.org/10.1016/j.intaccaudtax.2018. 05.002

Immanuel, R., \& Yuyetta, E. N. A. (2014). Analisis Faktor-Faktor Yang Mempengaruhi Penetapan Audit Fees (Studi Empirik Pada Perusahaan Manufaktur di BEI). Diponegoro Journal of Accounting, 3(3), 816-827.

Jensen, C. M., \& Meckling, H. W. (1976). Theory of The Firm: Managerial Behavior, Agency Costs and Ownership Structure. Journal of Financial Economics 3, 3, 350-360. https://doi.org/10.1177/0018726718812602

Nicolin, O., \& Sabeni, A. (2013). Pengaruh Struktur Corporate Governance, Audit Tenure, dan Spesialisasi Industri Auditor terhadap Integritas Laporan Keuangan. Diponegoro Journal of Accounting, 2(3), 1-12.

Nikkinen, J., \& Sahlström, P. (2004). a General Framework for Audit Pricing? International Journal of Auditing, 8, 253-262.

O'Sullivan, N. (2000). The impact of board composition and ownership on audit quality: Evidence from large UK companies. British Accounting Review, 32(4), 397-414. https://doi.org/10.1006/bare.2000.0139

Primasari, R., \& Sudarno. (2013). Pengaruh Koneksi Politik dan Corporate Governance terhadap Audit Fee. Dipenogoro Journal of Accounting, 2(2), 1-15.

Taqi, M., Rahmawati, R., Bandi, B., Murni, S., \& Warsina, W. (2020). Audit Quality Attibutes and Client Factors. AFRE (Accounting and Financial Review), 3(1), 1-13. https://doi.org/10.26905/afr.v3i1.3884

Utamaningsi, L. (2019). Political Connection, Auditor Selection, Audit Fee \& Audit Report Lag: A Review in Indonesia. International Journal of Progressive Sciences and Technologies, 13(2003), 167-173.

Uusitalo, S., Salmela, M., \& Nikkinen, J. (2013). Addiction, agency and affects - Philosophical perspectives. NAD Nordic Studies on Alcohol and Drugs, 30(1-2), 33-50. https://doi.org/10.2478/nsad-2013-0004

Wang, Z., Chen, M. H., Chin, C. L., \& Zheng, Q.
(2017). Managerial ability, political connections, and fraudulent financial reporting in China. Journal of Accounting and Public Policy, 36(2), 141-162. https://doi.org/10.1016/j.jaccpubpol.2017.0 2.004

Watts, R. L., \& Zimmerman, J. L. (1990). Positive Accounting Theory: A Ten Year Perspective. The Accounting Review, 65(1), 131-156.

Yao, D. F. T., Percy, M., \& Hu, F. (2015). Fair value accounting for non-current assets and audit fees: Evidence from Australian companies. Journal of Contemporary Accounting and Economics, 11(1), 31-45. https://doi.org/10.1016/j.jcae.2014.12.003 